\title{
Consumer Behavior and Patterns During the Covid-19 Pandemic in Indonesia
}

\author{
Intan Nurrachmi ${ }^{1 *}$, Setiawan $^{2}$ and Udin Saripudin ${ }^{1}$ \\ ${ }^{1}$ Sharia Faculty, Universitas Islam Bandung, Indonesia \\ ${ }^{2}$ Accounting Department, Politeknik Negeri Bandung, Indonesia \\ *Corresponding author Email: intannurrachmi@gmail.com
}

\begin{abstract}
The Covid-19 pandemic has changed many human life arrangements so that new habits have emerged that lead to different lifestyles from before. This study seeks to explain consumer behavior and habit patterns during the Covid-19 pandemic in Indonesia. This research was conducted through literature study and direct observation of consumer behavior in shopping. The results reveal how consumers in Indonesia must adapt during the Covid-19 pandemic. In addition, it explains how new consumer habits are in buying products from providers.
\end{abstract}

\section{Keywords: Consumer behavior, Covid 19 pandemic, Lifestyle}

\section{INTRODUCTION}

Marketing managers at the forefront of the marketing department should know how consumer behavior makes purchasing decisions, which will be the key to success in marketing activities [1]. Consumer behavior will appear when someone's behavior has a need or desire to get something. Humans are often faced with various choices to meet their needs. Understanding behavior is very important to project consumer demand for products and is used as important capital for companies to achieve their business development goals [2].

Behavior is an activity and activity of the organism concerned, both activities that can be observed or that cannot be observed by others [3]. Skinner says that behavior is a responsible person's reaction to a stimulus [4]. Engel et al. explaining that consumer behavior is an action that is directly involved in obtaining, consuming, and spending products and services, including the processes that precede and follow from this action [5].

Several factors influence consumer decisions in buying a product: cultural factors, social class, family, and clubs (reference group) [6]. Kotler et al. state that the factors influencing consumer behavior are cultural, social, personal, and psychological factors [7]. Meanwhile, Swastha and Irawan form that the factors affecting buying decisions are culture, social class, small reference groups, family, experience, personality, attitudes and beliefs, and self-concept [8].

\begin{abstract}
They usually shop at the beginning of the month because they have finished their payday buying habits. Also on weekends for weekly workers. And at times when facing Eid, most people shop; as a result, the prices go up. The symptoms of buying habits recur every year. Therefore, traders have been prepared long in advance to face the arrival of buying habits.

There are differences in consumer behavior in normal situations and crises, such as during a disaster, in this case, the Covid-19 outbreak. The Covid-19 epidemic has not only forced some efforts to redesign business models under pandemic conditions. The attack has also changed how consumers behave. Inventure's Managing Partner, Yuswohady, said that the changes caused by the Covid-19 pandemic are irreversible or will not go back to the beginning. "This will create a new order, a new normal."

Consumer behavior during the Covid-19 pandemic needs further investigation because there has been no in-depth research on this. This study aims to identify various consumer behaviors during the Covid-19 pandemic so that business actors have an overview of how to prepare for and overcome these behavior changes.
\end{abstract}

\section{METHODOLOGY}

This study uses a qualitative descriptive method to explain how consumer behavior in shopping during 
the Covid-19 pandemic. In this study, data collection techniques were carried out through literature studies and direct observation of consumer behavior in shopping. Data analysis was carried out simultaneously through continuous analysis with data analysis techniques for qualitative research with the following stages: data collection, data reduction, data presentation, and interpretation.

\section{RESULTS AND DISCUSSION}

\subsection{How Consumers are Adapting to the COVID-19 Pandemic}

The economic motive is a person's desire to be able to meet their needs. Needs can be defined as all desires that must be fulfilled both goods and services; if not fulfilled, it can affect their survival or negatively impact. Human needs are very many and varied, and even continue to increase constantly following civilization's development, advances in science and technology [9].

In the economic aspect, consumption has great urgency because there is no human life without consumption. So that economic activity always leads to meeting human consumption needs. When ignoring consumption is equivalent to neglecting human life and neglecting social duties in life [10]. This means that consumption is one of the human needs that must be fulfilled.

The theory of consumer behavior (consumer behavior) mentioned that consumers would choose among a wide selection of faces using their resources. According to Betham, hes is said that in general, no one can know what is good for their interests except the person himself [11].

To fulfill their daily needs, humans carry out economic activities together as social beings. These economic activities include production, consumption, and distribution activities. Production activities are activities to produce goods or services; consumption activities consume or reduce the value of these goods or services. At the same time, distribution is the process of distributing goods and services. These three main economic activities are interrelated and depend on each other in supporting the fulfillment of human needs.

The Large-Scale Social Restrictions (PSBB) implemented in Indonesia over the past few months have proven to be changing people's behavior patterns. According to Effendi Haslim Hong, who was quoted from Bisnis.com, the Covid-19 outbreak has affected all aspects of human life [12]. Most of the people had to carry out their daily activities from home only for work and study after implementing the PSBB. Apart from that, the big influence is also felt by everyone in their role as a consumer.

According to Effendi, there are three new consumer trends due to the Covid-19 pandemic, namely [12]: a) As a result of social distancing, consumers have switched to making purchases by reducing direct contact and low contact to purchase online. Closed traditional shops make consumers switch to making purchases. Online. Various needs such as health equipment, health supplements, clothes, kitchen utensils, food ingredients they buy online, take away, or home delivery. Various equipment such as cooking tools or baking tools, to garden equipment, become online search items. Consumers try to fill their time with new activities at home. Food purchases at restaurants are forced only to be done through delivery by online motorbikes. This new habit is predicted to last quite a long time.

b) Also related to social distancing, introverted consumers will increasingly enjoy the lifestyle cocooning. This term was introduced by futurist Faith Popcorn to denote a person who wants life in solitude and avoids direct interaction with other people, like a cocooned caterpillar that makes silk fibers wrap around itself. This pandemic makes the future come faster. Augmented Reality (AR) entertainment equipment where people can enjoy virtual trips to other countries or other entertainment only through an AR headset. For example, Japan is already trying to broadcast baseball and marathon games behind closed doors via AR's beta version. The gaming industry will be even more successful. Due to the large number of sports activities that had to be stopped, many people have switched to esports. ATP Tennis recently completed the famous Mutua Madrid Open tennis match in esports with British winner Andy Murray, beating Belgium's David Goffin. In real life, Andy Murray is still in the process of recovering from his hip surgery. This sports event is a smart choice because instead of empty, it's better to have a replacement version. With an event like this, it makes fans even a little entertained.

c) Health concerns will be even greater. Countries in the world will increasingly pay attention to health issues and protect national borders properly. This needs to be done to avoid another pandemic. Traveling across countries will not be as easy as we have experienced before. Data or a person's immunity certification will become a required document when traveling abroad. When certain countries start to reopen airports, they carry out Covid-19 tests on passengers. Indeed, globalization will be held back for a while. For this reason, it is predicted that domestic tourist arrivals will increase faster than abroad. At the individual level, the concern for mental and physical health will be even greater. Consumers learn to eat healthy foods, take supplements and 
multivitamins, exercise, and meditate. If previously, consumers were very difficult to get invited to consume herbal medicine, now all their herbal medicine is willing to drink. Meditation practice is also a good choice for maintaining mental health. Society has become increasingly religious at this difficult time. Along with that, the need for online psychiatric counseling and coaching will be even higher in the future.

\subsection{Patterns of Consumer Behavior during the Covid-19 Pandemic}

Changes in consumer behavior patterns when facing a pandemic is very much influenced by many factors. Meanwhile, Nurlatifah, followed by marketeers.com, stated behavior change could be seen in three decision-making perspectives, namely Rational, Experiential, and Behavioral [13].

\section{a) Rational}

In this perspective, consumers make sensible purchasing decisions by emphasizing functional and economical aspects. Most commonly, consumers will choose brands that offer the best prices, features, and services. In a pandemic situation, consumers no longer consider rationality, especially for goods that are the main needs of health protection. Items such as masks, hand sanitizers, and disinfectants will be purchased regardless of the brand and price. Purchasing decisions are also based more on the availability and ease of getting goods.

b) Experiential

Purchasing decision making is influenced by feelings related to product consumption. Purchase decisions are based on a unique experience. Consumers decide to go to the cinema to watch movies or listen to music by watching live concerts more because they want to experience a unique and different experience than watching movies or listening to music at home. The experience of watching together with many people with a big screen or a stage equipped with a good sound system is a sensation that will not be obtained if done at home. Covid-19 transmission occurs due to close interaction. So it will be very easy to spread out in the crowd. With reasons of fear of contracting Covid-19, consumers are reluctant to go to the cinema or a music concert venue. In this situation, to satisfy their desires, consumers prefer to enjoy them at home and change their purchasing decisions with online products by subscribing to Netflix, for example.

c) Behavioral

Purchase decisions that respond to environmental influences, for example, because the atmosphere is a calm and comfortable place. Consumers go to a café or restaurant not only to enjoy food or drink but more to enjoy a quiet and comfortable place where consumers can sit longer while working or chatting with business partners. With the reason of Covid-19 transmission, consumers are reluctant to visit and to get food that consumers prefer to deliver take away or buy it using services.

According to Kiril Mankovski, quoted from Ceknricek.com, there are at least six new consumer behaviors known as Crisis Persona (Crisis Persona) identified as emerging in Indonesia, namely The Adaptive Shopper, The Brave One, The Market Observer, The Bored Homebody, The Health Nut, and The Yearning Traveler [14].

a) Adaptive Shopper is those who are adapting to new ways to meet their needs by shopping online. This is evidenced by the increasing use of shopping applications by 800 percent. Tsai describes the travel model adaptive Shopper as follows [15]:

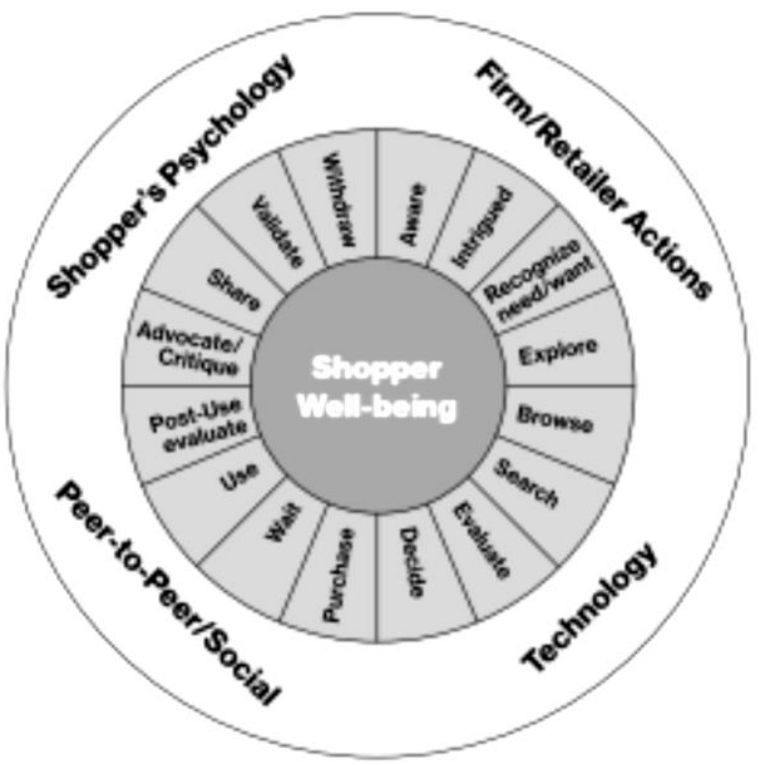

Figure 1. The Needs-Adaptive Shopper Journey Model

In this figure, it can be seen that the most important thing that companies or merchants should pay attention to is the consumer. In the conditions of the Covid-19 pandemic, the community is faced with not many alternative options for transactions to prevent the spread of the Covid-19 virus. Consumers reduce contact physical(social distancing) in making transactions, so consumers prefer to transact virtually or online [16].

b) The Brave One is a worker who is at the forefront. Namely, those who continue to work and serve the community, their mobility does not 
experience changes, and application consumption is not as big as others.

c) The Market Observers keep a close eye on stocks and currencies for financial implications or market opportunities. Economic market conditions that change so fast are an opportunity for these observers.

d) The Bored Homebody is those who spend their time looking for entertainment by playing games or watching. They are constantly at home and have plenty of time, which increases their entertainment-seeking activity.

e) The Health Nut, those who use health applications to monitor their physical and mental conditions. They have a lot of free time to monitor health conditions using applications that can deal with stress, and efforts to maintain health are increasing.

f) The Yearning Traveler were those who thought about the journey that would take place after the crisis ended. They use travel apps to search for interesting destinations to visit when the pandemic ends.

According to Indra Utoyo, Director of Digital and Information Technology (IT) of Bank Rakyat Indonesia, explained that there were four changes in aspects of consumer behavior after Covid-19, namely lifestyle, emphatic society or social interaction, going on a regular and the pyramid of consumer needs [17]. The economy is now staying in a home-style, interestingly, now the consumption does not decrease but comes home. Delivery grows coming home. Consumer needs are currently shifting from food, clothing, financial services, and even health to those who have used digital systems. Indra said that BRI had implemented technology and improved services in serving customers, one of which is through mobile banking. In April 2020, Internet Banking / BRImo and SMS Banking continued to experience a YoY increase of $73.08 \%$ in terms of the number of transactions and $21.08 \%$ in transaction volume. Throughout 2020, electronic banking transactions at Bank BRI, both through digital and non-digital platforms, also reached 2.73 billion transactions with a nominal volume of Rp1,928 trillion or YoY for April. It grew by $18.71 \%$ for the number of transactions and $794 \%$ for transaction volume.

According to Anindita, there are four changes in consumer behavior that are currently happening, namely [18]:

a) Consumers Tend to Focus on Prices

According to McKinsey, when in the middle of a crisis, consumers tend to prioritize lower prices. In normal situations, consumers usually prioritize value over cost. However, in crisis times, consumers need a stronger reason to buy something at a high price. In his survey, McKinsey found that more than 33\% of bottled water consumers are quite satisfied with bottled water, which is cheaper. They also admit that they no longer need the benefits of bottled water at a higher price. Likely, the difference in quality between cheaper and expensive bottled water is also insignificant.

b) Consumer Spending Patterns Focused on Certain Types of Products

Since the emergence of COVID-19, especially since social distancing was implemented, people tend to buy necessities and whatever is needed in their homes. Some of the products currently a priority for consumers are food ingredients (especially durable ones) and medical supplies (including masks and hand sanitizers). However, secondary needs such as household utensils are still in high demand (possibly because people spend their time at home).

As for several sectors that have benefited from the midst of the COVID-19 pandemic, namely wholesale, telecommunications, pharmaceuticals, food and beverages, and logistics, although food and drinks are still sought after, many restaurants are losing money because they cannot serve dine-in. Meanwhile, the tourism and transportation sectors were the sectors that suffered the most losses because consumers canceled their travel plans and made refunds for tickets and accommodations they had ordered.

c) Consumers from Different Generations Choose Online Shopping

Since COVID-19, outlets retail have started to lack visitors. And after the PSBB was implemented, retailers were temporarily forced to close their outlets in various shopping centers. People's purchasing power may decrease, but that does not mean product retail, such as clothing, has lost demand. Today, consumers from all walks of life and generations continue to shop for products retail, such as clothing, cosmetics, skincare, and electronics online.

d) Consumers Shop Collectively

One of the trends that have emerged as a result of the COVID-19 pandemic is group buying. This term refers to the purchasing power of consumers to buy products collectively for a discount. Consumers prefer to purchase products at lower prices but in large quantities. They can purchase these products individually or in collaboration with several other buyers to get a lower price.

\section{CONCLUSION}

This research reveals that consumers try to reduce physical contact during shopping, and for some people, this is very much enjoyed as a lifestyle. In 
addition, many people are increasingly aware and concerned about healthy lifestyles. However, these changes in behavior patterns come from three perspectives, namely rational, experiential, and environmental responses.

Based on this research, it is expected that product providers will follow health standards in serving consumer needs. In addition, product providers are required to be more creative in marketing their products to remain competitive.

\section{REFERENCES}

[1] I. Nurrachmi, S. Setiawan, and U. Saripudin, "Motivation for purchasing halal products: The influence of religiosity, trust, and satisfaction," Humanities \& Social Sciences Reviews, vol. 8, no. 5, pp. 210-218, 2020.

[2] D. Suhartanto, C. Gan, I. S. Sarah, and S. Setiawan, "Loyalty towards Islamic banking: service quality, emotional or religious driven?," Journal of Islamic Marketing, vol. 11, no. 1, pp. 66-80, 2020, doi: 10.1108/JIMA-01-2018-0007.

[3] D. Suhartanto, N. H. Farhani, M. Muflih, and Setiawan, "Loyalty intention towards Islamic Bank: The role of religiosity, image, and trust," International Journal of Economics and Management, vol. 12, no. 1, pp. 137-151, Jun. 2018.

[4] B. F. Skinner, The Behavior of Organism: An Experimental Analysis. BF Skinner Foundation, 2019.

[5] J. F. Engel, R. D. Blackwell, and P. W. Miniard, Consumer Behavior, 6th ed. Chicago, New York: Dryden Press, 1995.

[6] B. Alma, Marketing Management and Service Marketing [Manajemen Pemasaran dan Pemasaran Jasa]. Bandung: Alfabeta, 2007.

[7] P. Kotler, G. Armstrong, J. Saunders, and V. Wong, "Principle of Marketing," in Principles of Marketing, 2002.

[8] B. Swastha and Irawan, Modern Marketing Management Management [Manajemen Pemasaran Modern Manajemen]. Yogyakarta: Penerbit Liberty, 2005.

[9] L. T. Rochmawan, Introduction to Microeconomics [Pengantar Ekonomi Mikro]. Semarang: Anindya, 2008.

[10] N. I. Sitepu, "Islamic Consumption Behavior in Indonesia" "[Prilaku Konsumsi Islam di Indonesia]," Jurnal Persfektif Ekonomi Darussalam, vol. 2, no. 1, pp. 92-106, 2016.

[11] P. Schofield, "Bentham, Jeremy (17481832)," in Encyclopedia of Law \& Society:
American and Global Perspectives, 2455 Teller Road, Thousand Oaks California 91320 United States: Sage Publications, Inc., 2007.

[12] G. F. K. Lawi, "Here's the Shift in New Consumer Behavior during the Covid-19 Pandemic" "[Begini Pergeseran Perilaku Konsumen Baru selama Pandemi Covid-19] | Ekonomi," Bisnis.com, May 15, 2020. https://ekonomi.bisnis.com/read/20200515/1 2/1240921/begini-pergeseran-perilakukonsumen-baru-selama-pandemi-covid-19 (accessed Sep. 24, 2020).

[13] H. Nurlatifah, "Changes in Consumer Behavior during a Pandemic and Possible Afterward "[Perubahan Perilaku Konsumen pada Masa Pandemi dan Kemungkinan Setelahnya]," Marketeers - Majalah Bisnis \& Marketing Online - Marketeers.com, May 04, 2020. https://www.marketeers.com/perubahanperilaku-konsumen-pada-masa-pandemidan-kemungkinan-setelahnya/ (accessed Sep. 24, 2020).

[14] "Analysts Call Covid-19 Generates New Consumer Behavior" "[Analis Sebut Covid19 Hasilkan Perilaku Konsumen Baru]," Validnews, May 2020. https://www.validnews.id/Analis-SebutCovid-19-Hasilkan-Perilaku-KonsumenBaru-okt (accessed Sep. 24, 2020).

[15] C. Tsai, "Introducing the Needs Adaptive Consumer," Rotman Management Magazine, Sep. 01, 2019.

[16] S. N. Fatoni, C. Susilawati, L. Yulianti, and Iskandar, "The Impact of Covid-19 on Consumer Behavior in Using E-Wallets in Indonesia" "[Dampak Covid-19 terhadap Perilaku Konsumen dalam Penggunaan EWallet di Indonesia]," Bandung, May 13, 2020.

[17] Suheriadi, "Collaboration is the Key to BRI Developing Safe Digital Banking" "[Kolaborasi Jadi Kunci BRI Kembangkan Digital Banking yang Aman]," Infobanknews, Feb. 20, 2020. https://infobanknews.com/topnews/kolabora si-jadi-kunci-bri-kembangkan-digitalbanking-yang-aman/ (accessed Sep. 24, 2020).

[18] K. Anindita, "Consumer Behavior During COVID-19 and How To Cope With It" "[Perilaku Konsumen Selama COVID-19 dan Cara Menghadapinya]," BusinessTech HashMicro, Apr. 29, 2020. 